\title{
広域災害時における災害廃棄物処理の 広域連携方策に関する研究
}

\author{
平山 修久 ${ }^{1} \cdot$ 河田 惠昭 ${ }^{2}$ \\ ${ }^{1}$ 正会員 人と防災未来センター（广 651-0073 兵庫県神戸市中央区脇浜海岸通 1-5-2) \\ E-mail:hirayaman@dri.ne.jp \\ 2 フェロー会員 京都大学教授 防災研究所巨大災害研究センター（† 611-0011 京都府宇治市五ケ庄）
}

\begin{abstract}
平常時の一般廃棄物排出量からみた災害廃棄物発生量である災害廃棄物量相対値を用いて，東海地震， 東南海・南海地震，首都直下地震に係る災害廃棄物に対する我が国の災害対応力を明らかにした。また， 行政の災害対応力を考慮した災害廃棄物処理期間推定モデルを構築した。

災害廃棄物の広域連携シミュレーションモデルを構築し, 首都直下地震における災害廃棄物処理に関す る数值シミュレーションを行った。その結果, サテライト方式あるいはバックヤード方式での全国連携に よる災害廃棄物処理に必要な処理期間は，それぞれ 1.95 年，1.80 年と推定された。また，広域災害時にお ける災害廃棄物対策では，都道府県間を越えた広域的な連携が重要となることを示しえた。
\end{abstract}

Key Words : emergency debris operation, wide-area cooperative measures, huge earthquake disasters

\section{1. 緒言}

地震や水害などの自然災害発生時には，家屋建築物の 倒壊や被災住宅より家財等の災害廃棄物が大量に発生す る. 災害時の廃棄物処理施策を的確かつ合理的に策定し, いかに迅速に市街地から廃棄物を取り除き，復旧・復興 において主役となるべき市民に対して，環境衛生面から 安心・安全を供与することが重要である。また，災害廃 棄物の処理においては，被災地からの搬出方法，仮置き 場や最終処分場での対応，燒却，リサイクルのための破 砕・選別方法など，様々な観点から検討していくことが 求められる。

これまでにも，自然災害における廃棄物の処理対策に

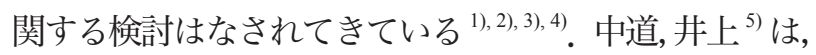
阪神・淡路大震災において，災害廃棄物の処理で適用さ れた処理技術について検討している，高月ら ${ }^{6)}$ は，災 害に起因する廃棄物として，阪神・淡路大震災における 家屋建築物の倒壊に伴う解体廃棄物の発生状況の調査か ら, 解体廃棄物の発生原単位を算出している。島岡 ${ }^{7)}$ は, 災害廃棄物の発生状況ならびに処理の経緯を整理し，災 害の種類とその災害廃棄物の特徵, 処理における課題に ついて検討している。平山，河田 ${ }^{8)}$ は，水害廃棄物に関 して，災害時の被害報における住家被害を考慮した水害 廃棄物発生量原単位を推定し, 限られた情報しか得られ
ない災害初動時においてもある程度の精度で，かつ，実 務的に使いやすい水害廃棄物発生量推計手法を提案して いる.

また，行政の災害対応という観点からも，災害廃棄物 対応について検討されている9), 10), 11), 12). 阪神・淡路大 震災後，厚生省生活衛生局水道環境部では震災廃棄物対 策指針を策定している ${ }^{13)}$ 。また, 環境省大臣官房廃棄物・ リサイクル対策部では，2004 年集中豪雨，台風災害を 踏まえ，水害時の廃棄物処理を適正かつ円滑に行うため の指針を策定している ${ }^{14)}$. 平山，河田 ${ }^{15)}$ は，水害時の 被災市町村の災害対応力を考慮した被害状況を示すひと つの指標として，災害廃棄物量相対值を導出している。

西南日本外帯における南海トラフに沿うフィリピン海 プレートの沈み込みによる巨大地震である想定東海地 震，東南海・南海地震，あるいは首都直下地震の切迫性 が指摘され，その発生が危惧されている。 七都県市廃亲 物問題検討委員会 ${ }^{16)}$ は，首都直下地震に係る震災廃亲 物処理に関する検討を行い，適正処理を実現するために は協力・支援体制を確立する必要があることを指摘して いる. 慶応義塾大学経済学部細田衛士研究会 ${ }^{17)}$ は, 仮 置場に着目して首都直下地震の震災廃棄物処理について 検討している。しかしながら，20以上の都府県に被害 が波及する東海・東南海・南海地震，あるいは 10 の都 県と政令指定都市に影響が及び，都市の災害に対する脆 
弱性が露呈する首都直下地震に係る災害廃棄物処理をい かに乗り切るのかについての検討はほとんどなされてい ない.

このような観点から，本研究では，行政の災害対応力 を考慮したうえで，広域都市災害時における廃棄物処理 の広域応援方策を提案することを目的とする.ここでは, 平常時の一般廃棄物排出量からみた災害廃棄物発生量で ある災害廃棄物量相対値 $W_{R}$ を用いて，東海地震，東南 海・南海地震，首都直下地震に係る災害廃棄物に対する 我が国の災害対応力について検討する。 そのうえで，首 都直下地震に係る災害廃棄物に着目し, 数值シミュレー ションにより, 大量の災害廃棄物を迅速に処理すること が可能となる広域応援のあり方について検討する。

\section{2. 阪神・淡路大震災における災害廃棄物発生量}

（1）阪神・淡路大震災における災害廃棄物に係る対応策 災害対策基本法第 40 条，ならびに第 42 条では，都 道府県，市町村は，防災基本計画に基づき，当該地域に 係る地域防災計画を作成し，及び毎年地域防災計画に検 討を加え，必要があると認めるときは，これを修正しな ければならないとしている ${ }^{18)}$. 都市直下地震であった 阪神・淡路大震災では，地域防災計画で事前に想定して いた量をはるかに超える災害廃棄物が発生した。

政府の廃棄物に関する法律面の措置として，阪神・淡 路大震災に対処するための特別の財政援助及び助成に関 する法律において，地方公共団体等に対する特別の財政 援助として市町が行う一般廃棄物処理施設の災害復旧に ついて，補助率の嵩上げが行われた ${ }^{11}$ 。また，甚大な 被害により, 都市機能が麻痺し, 社会的, 経済的影響が きわめて大きく, 阪神・神戸地域の都市機能の停止が日 本全国に大きな社会的不安と経済的損失を生じさせてい るという特別の事情に鑑內，損壊した家屋，事業所等の 解体, 処理については, 被災者の負担の軽減を図るため, 廃棄物として市町が解体・処理し, 国はその費用の二分 の一を補助する，という特別の措置，つまり公費による 処理方針が講じられた ${ }^{19}$.

\section{（2）阪神・淡路大震災での災害廃棄物発生量}

災害時の廃裹物処理施策を的確かつ合理的に策定する ためには,災害廃棄物処理量の推定が必要となる。しか しながら, 災害廃棄物発生量の推定は非常に困難であり, 解体必要家屋数等が次第に判明するにともない適宜修正 された。阪神・淡路大震災で発生した災害廃棄物の量は, 住宅・建築物系で 1450 万 $\mathrm{t}$, 公共公益施設系で 550 万 $\mathrm{t}$, 総計 2000 万 $\mathrm{t}$ と推計されている ${ }^{20)}$.

これまでにも，災害廃棄物対策分野においても，阪神・
淡路大震災での災害廃棄物の発生原単位の検討はなされ てきている.

高月ら ${ }^{21)}$ は，原単位は重量と容量ベースで推定して おり, 阪神・淡路大震災での木造家屋の廃棄物重量原単 位を $0.40 \sim 0.61 \mathrm{t} / \mathrm{m}^{2}$ と推定している. 渡辺 ${ }^{22)}$ は, 阪神・ 淡路大震災での廃棄物発生の見積もり方法について調査 し, 大阪市での 800 棟の解体実績から, 廃棄物発生量 を $96 \mathrm{~m}^{3} /$ 戸であったと推定している．また，住宅作業解 体処理業連絡協議会など業界で得られている值として, $39.7 \mathrm{t} /$ 戸〜 44.7t/ 戸と報告している.

\section{3. 行政の災害対応からみた想定地震に係る災害 廃棄物発生量}

\section{（1）想定地震における災害廃棄物量相対值 $W_{R}$}

西南日本外帯における南海トラフに沿うフィリピン海 プレートの沈み込みによる巨大地震である想定東海地 震, 東南海・南海地震, あるいは首都直下地震の切迫性 が指摘され，その発生が危惧されている，政府の中央防 災会議における専門調査会では, これらの想定地震に係 る被害想定を行っている ${ }^{23), 24), 25)}$.

そこでは，地震の摇れ，液状化，火災による消失など 各要因による建物被害量と 1 棟当たり床面積から被害面 積を算出し, 表 -1 に示す面積当たり災害廃棄物発生量 原単位を用いて災害廃棄物発生量の推定を行っている。

平山，河田 ${ }^{8)}{ }^{15)}$ は，災害廃棄物量を平常時の 1 年間 での一般廃棄物排出量であるごみ総排出量で除した災害 廃棄物量相対值 $W_{R}$ を, 被災市町村の災害対応力を考慮 した被災状況を示す指標のひとつとして提案している. ここでは, 東海地震, 東南海・南海地震, 首都直下地震 としての東京湾北部地震に対して, 我が国がどの程度の 災害対応力を有しているのかを把握することを目的とし て, 中央防災会議の専門調査会の想定結果，ならびに, 平成 15 年度の全国の 3155 市区町村, 848 一部事務組 合におけるごみ総排出量 ${ }^{26)}$ からみた災害廃暂物量相対 值 $W_{R}$ を算出した。 それぞれの想定地震における被害と 災害廃棄物量相対值 $W_{R}$ を表 -2 に示す。

これより, 想定地震における全国のごみ総排出量 5161 万 $\mathrm{t}$ からみた災害廃棄物量相対值 $W_{R}$ は, 9.5 ケ 月，16.0 ケ月，22.3 个月となっている。阪神・淡路大 震災での全国のごみ総排出量からみた災害廃棄物量相対

表 -1 被害想定手法における災害廃棄物発生量原単位

\begin{tabular}{|c|c|}
\hline 被害要因 & 面積当たり災害廃衰物重量 $\left(\mathrm{t} / \mathrm{m}^{2}\right)$ \\
\hline 木 造 & 0.6 \\
非木造 & 1.0 \\
火災による焼失 & 0.23 \\
\hline
\end{tabular}


表 -2 想定地震における災害廃棄物発生量ならびに災害廃棄物量相対値

\begin{tabular}{|c|c|c|c|c|}
\hline & 東海地震 & 東南海・南海地震 & 首都直下地震 & 阪神・淡路大震災 \\
\hline 建物被害（棟） & 23 万〜 46 万 & $328,600 \sim 628,700$ & 23 万〜 85 万 & 104,004 \\
\hline 避 難 者数（人） & 190 万 & 500 万 & 700 万 & 316,678 \\
\hline 断 水人数 (人) & 550 万 & 1,600 万 & 1,100 万 & (127 万戸) \\
\hline 災害廃棄物（t ） & 4,100 万 & 6,900 万 & 8,300 万〜 9,600 万 & 2,000 万 \\
\hline $\begin{array}{c}\text { 災害廃棄物量相対値 } \\
W_{R} \text { (全国) (ケ月) }\end{array}$ & 9.5 & 16.0 & $19.3 \sim 22.3$ & 4.7 \\
\hline
\end{tabular}

值 $W_{R}$ は 4.7 ケ月である. 阪神・淡路大震災では，災害 廃棄物処理に関する災害対応を通して得られた教訓のひ とつとして, 多方面かつ広域的な連携の強化があげられ ている ${ }^{12)}$ 。つまり, 災害廃棄物対応という観点からは, 被災地域の災害対応力を超えた災害であったといえる。

想定地震における災害廃棄物量相対值 $W_{R}$ は，阪神・ 淡路大震災での災害廃棄物量相対值の 2.0 倍以上であ り, 首都直下地震では 4.7 倍となっている. したがって, 行政の災害廃棄物処理対応という観点からは，首都直下 地震など想定地震における災害廃棄物は被災地域だけの 問題ではないといえる.

\section{（2）災害廃棄物処理期間推定モデル}

阪神・淡路大震災以前の災害では，全壊した建物だけ を災害廃棄物とみなし，収集，運搬，処分については市 町村の事業とされていたが，解体は所有者の責任と分担 で行うこととされてきた。阪神・淡路大震災では，損壊 した家屋, 事業所等の解体, 処理については, 廃棄物と して市町が解体，処理することとなった。したがって, 災害廃棄物は, 膨大な倒壊家屋等のがれき処理が中心と なる。一方, 平常時では, 家屋解体に伴う廃棄物は産業 廃棄物として区分され，污染者負担原則に基づき，排出 事業者が責任をもって処理することを原則としている. つまり，一般廃棄物と産業廃棄物の区分は，そのままで は災害時には通用しない，ということである。

災害廃棄物量相対值 $W_{R}$ は，あくまでも，行政の災害 対応力を考慮した災害廃棄物量であり，必ずしも災害廃 棄物の処理に要する期間を表すものではない. また，被 災者が避難した場合でも, 被災地域内で生活を営む限り において，一般廃棄物は排出されることとなる。

ごみ総排出量は, 行政の廃棄物処理に係る住民サービ スを実施する際に必要となる業務量を示すひとつの指標 であると考えられる。したがって，災害廃裹物を処理す るために平常時のごみ総排出量から, 廃衰物関係団体や 民間業者との協働等によってどの程度まで廃棄物処理対 応力を向上させることができるのかにより, 災害廃棄物 の処理期間が左右される。つまり, 廃棄物処理対応力係 数 $\alpha(-)$ を平常時のご夕総排出量からどの程度まで処 理能力を向上させたのかを示す比と定義すると, 災害廃

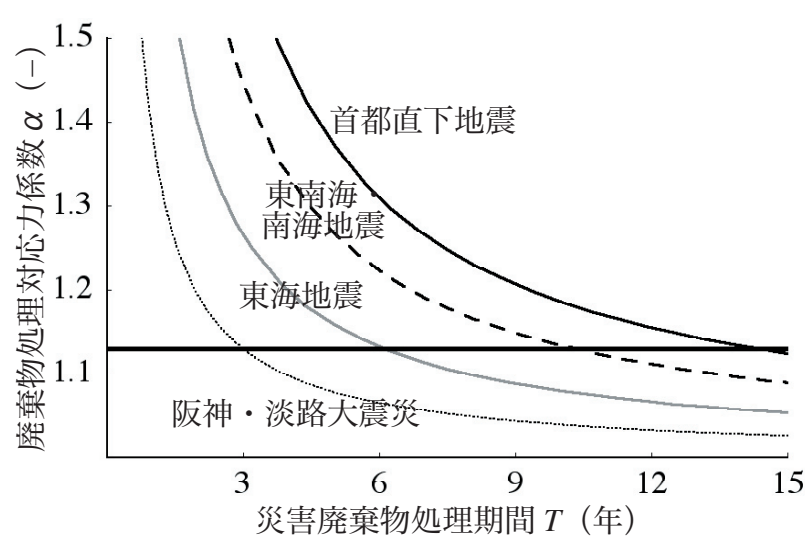

図 -1 想定地震に係る災害廃棄物処理期間

棄物発生量 $W_{D}(\mathrm{t})$, 平常時の 1 年間のごみ総排出量 $W_{0}$ $(\mathrm{t} /$ 年), 災害廃棄物処理期間 $T$ (年) は以下の式で表さ れる。

$$
W_{D}+W_{0} T=\alpha W_{0} T
$$

図 - 1 に想定地震に係る災害廃棄物を，全国の一般廃 棄物処理能力に対する廃棄物処理対応力係数 $\alpha$ と災害 廃棄物処理期間 $T$ との関係を示す。

阪神・淡路大震災での災害廃棄物処理期間は 3 年で あったことから，阪神・淡路大震災における全国の一 般廃棄物処理能力に対する廃棄物処理対応力係数 $\alpha$ は 1.13 となる。 これより, 想定地震に係る災害廃棄物を 阪神・淡路大震災と同じ廃棄物処理対応力係数で処理す る場合，その処理期間は，東海地震で 6.2 年，東南海・ 南海地震で 10.4 年, 首都直下地震で 14.4 年となる。 つ まり, 首都直下地震では, 全国の市町村, 一部事務組合 が, 平常時の 1 年間のごみ総排出量 5161 万 $\mathrm{t}$ 年に加え て， 666 万 $\mathrm{t}$ 年の首都直下地震に係る災害廃棄物を処理 するという応援活動を 14.4 年継続することで, 首都直 下地震に係る災害廃棄物处理が完了する，といえる。

一方，阪神・淡路大震災では，り災世帯の $99.3 \%$ が

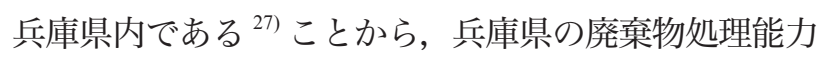
に着目すると, 兵庫県のごみ総排出量 244 万 $\mathrm{t} /$ 年から みた災害廃棄物量相対值 $W_{R}$ は 98.3 ヶ月である。阪神・ 淡路大震災では, 大阪湾広域臨海環境整備センターが災 害廃棄物を受け入れるなど広域応援による処理体制が確 立された ${ }^{28)}$.このような広域応援による処理体制のも 
とで, 災害廃暂物処理が 3 年で完了したことから, 阪神・ 淡路大震災における兵庫県の廃棄物処理対応力係数 $\alpha$ は 3.73 となる。 また，地震による災害廃棄物は倒壊家 屋等のがれき処理が中心となることから, 平成 15 年度 における兵庫県の産業廃棄物のがれき類推計排出量 122 万 $\mathrm{t}^{29)}$ からみた場合, 平常時のがれき類排出量の 5.46 倍 の災害廃暂物を処理することができた，といえる。

以上のことから, 東海地震, 東南海・南海地震や首都 直下地震に係る災害廃棄物処理は被災地域の夕の課題で はなく，国難であるとの認識にたち，この国難をいかに 克服していくのかについて検討しておくことが重要であ り，急務であると考える。

\section{4．首都直下地震における広域連携方策}

\section{（1）災害廃棄物の広域連携シミュレーションモデル}

災害対策基本法第 43 条では，二以上の都道府県の区 域の全部又は一部にわたり特定事項について防災行政の 総合的な運営を図るため設置された都道府県防災会議の 協議会が作成する都道府県相互間地域防災計画の作成に ついて定められている ${ }^{18)}$. 阪神・淡路大震災の経験から， ごみ処理，がれき処理への応援といった市町間の連携， 域外処理における委託先市町との調整や民間業者の受入 能力の確認など府県間での事前調整といった府県間の連 携，広域処分場の確保，民間業者との連携など，多方面 かつ広域的な連携の重要性が指摘されている ${ }^{12}$.

現在，自治体と業界団体との震災時の廃棄物処理に関 する協力支援体制の確立，あるいは，都道府県間，市町 村間，県と市町村等との相互応援協定などの応援体制の 整備が図られてきている ${ }^{16), 30)}$. しかしながら，これら の相互応援協定は各都道府県や各市町村が定めた地域防 災計画に基づいたものであり, 複数の都府県が甚大な被 害を受けるスーパー広域災害となる東海・東南海・南海 地震や首都直下地震における廃棄物処理をいかに克服す るのかという観点から十分に検討されているとはいいが たい.

以上の観点から，本研究では，都道府県間の広域連携 に着目し，広域災害に拀ける広域連携方策について，災 害廃棄物の広域連携モデルを用いた数值シミュレーショ ンにより検討する.

ここでは，都道府県間の広域連携に着目し，都道府県 における災害廃棄物対応力と都道府県間の災害廃棄物運 搬量によりモデルを記述する。図 -2 に災害廃棄物の広 域連携モデルを示す。ここに, 災害廃棄物発生量 $W_{D}(\mathrm{t})$, 被災都道府県 $\mathrm{A}$ の処理能力 $\alpha_{\mathrm{A}} W_{0, \mathrm{~A}}$ ( $\mathrm{t} /$ 年), 応援都道府 県 $\mathrm{B}$ の処理能力 $\alpha_{\mathrm{B}} W_{0, \mathrm{~B}}(\mathrm{t} /$ 年 $)$, 被災地 $\mathrm{A}$ から応援都 道府県 $\mathrm{B}$ への災害廃棄物運搬量 $W_{T(\mathrm{~A}, \mathrm{~B})}(\mathrm{t} /$ 年) である.

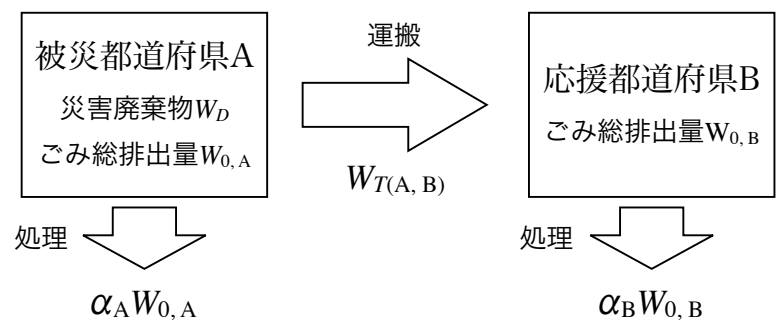

図 -2 災害廃棄物の広域連携モデル

本研究は，あくまでも，広域災害における広域連携方策 を検討し，広域連携の具体的な検討に資する基礎資料を 導出するものであることから, 市町村業務である収集過 程, 処理過程, 災害廃棄物の分別, 仮置き場の確保など については扱わない.

また, 災害廃棄物処理量と災害廃棄物運搬量に関して,

$$
\begin{gathered}
W_{T(\mathrm{~A}, \mathrm{~B})}=\left(\alpha_{\mathrm{B}}-1\right) W_{0, \mathrm{~B}} \\
\alpha_{i} W_{0, i} \leqq W_{0, i}+W_{i d, i} \\
W_{T(A, B)} \leqq W_{C a r g o}(\mathrm{~A}, \mathrm{~B})
\end{gathered}
$$

をシミュレーションモデルにおける制約条件とした。こ こに, 都道府県 $i$ の平常時の 1 年間のごみ総排出量 $W_{0, i}$ $(\mathrm{t} /$ 年), 都道府県 $i$ の平常時の 1 年間の産業廃棄物がれ き類排出量 $W_{i d, i}(\mathrm{t} /$ 年), $\mathrm{A}$ から $\mathrm{B} へ$ 都道府県間流動 量 $W_{\text {Cargo (A, B) }}(\mathrm{t} /$ 年) である。 それぞれ，平成 15 年度ご 从総排出量 ${ }^{31}$, 平成 15 年度都道府県別がれき類推計排 出量 ${ }^{29)}$ ，2000 年都道府県間流動量 ${ }^{32)}$ を用いた。応援都 道府県への災害廃棄物運搬量, 応援都道府県におけるご 队総排出量, 処理量との物質収支が成り立つものとする. つまり, 応援都道府県の処理量以上の災害廃棄物を運搬 するなどの災害廃棄物対応力を超えるような応援負荷は かけない，ということである。また，ここでは，災害廃 棄物を処理するための廃棄物処理対応力向上は, 平常時 の産業廃棄物におけるがれき類排出量までは可能とし, 災害廃棄物の運搬量は，平常時の貨物純流動量までは可 能であるとした。つまり, 都道府県 $i$ の廃棄物処理対応 力係数 $\alpha_{i}$ の最大值は $1+W_{i d, i} / W_{0, i}$ となり, 平常時の産業 廃棄物におけるがれき類排出量以上の災害廃棄物を処理 することはできない，ということである.

なお，ここでは，応援都道府県の処理能力と都道府県 間の運搬能力による制約条件のもとで，処理期間が最小 となるように，災害廃棄物を応援都道府県に最適配分す るものとした。

\section{（2）広域連携シナリオの設定}

ここでは，広域災害として，想定地震のなかで災害廃 棄物発生量が最大となる首都直下地震をとりあげる。 ま た，首都直下地震として想定されている 18 タイプの地 
表 -3 首都直下地震における都道府県別災害廃棄物量

\begin{tabular}{|c|c|c|}
\hline & $\begin{array}{c}\text { 災害廃棄物発生量 } \\
\text { (万 } \mathrm{t})\end{array}$ & $\begin{array}{c}\text { 災害廃棄物量相対値 } \\
W_{R} \text { (ケ月) }\end{array}$ \\
\hline 埼玉県 & 600 & 27.8 \\
千葉県 & 900 & 46.5 \\
東京都 & 6700 & 155.4 \\
神奈川県 & 1400 & 47.2 \\
\hline
\end{tabular}

震動のうち, 被害が最大と推定されている東京湾北部地 震, $\mathrm{M} 7.3$, 冬, 夕方 18 時の想定地震について検討する. 首都直下地震における都道府県別の災害廃棄物発生量 ならびに災害廃棄物量相対值 $W_{R}$ を表 -3 に示す。これ より，東京都に約 7 割の災害廃棄物が集中していること がわかる。

本研究では，1）被災都県個別に対応，2）首都圈で の連携，3）個別方式による全国連携，4）サテライト 方式による全国連携，5)バックヤード方式による全国 連携，の 5 つの広域連携方法について検討する。

1) 被災都県個別に対応では，被災都県である埼玉県, 千葉県，東京都，神奈川県がそれぞれ個別に災害廃亲物 処理を実施するものとする。 なお，災害廃棄物処理関連 施設には被害がなく，現状の処理能力を維持できるもの と仮定する。

2) 首都圈での連携では, 茨城県, 栃木県, 群馬県, 埼玉県, 千葉県, 東京都, 神奈川県, 山梨県の 1 都 7 県が連携して災害廃棄物処理を実施するものとする。東 京都における災害廃棄物量が膨大であることから，災害 廃棄物のフローは図 -3 に示すように東京都から 7 県に 運搬し，1 都 7 県で処理を実施するものとする。なお, 神奈川県，千葉県，埼玉県は，各自の災害廃棄物処理が 完了してから応援を行うものとした。

3) 個別方式による全国連携では，46 道府県がそれぞ れ東京都から災害廃棄物を運搬し，46 道府県で処理を 実施するものとする。なお，災害廃棄物が発生する神奈 川県，千葉県，埼玉県については，それぞれ発生した災 害廃棄物の処理完了後に応援を実施するものとした。

4）サテライト方式による全国連携は，全国を北海道・ 東北, 首都圏, 北陸, 中部, 関西, 中国, 四国, 九州 · 沖縄という8 地方に区分し, 被災地からそれぞれの地方 の中核となる府県に災害廃棄物を運搬し，その後，地方 のそれぞれの道府県に運搬する，という2 段階による災 害廃育物運搬方式である. 図 -4 に一例として中部地方 のフローを示す。つまり，被災地から地方を代表して災 害廃率物を運搬し，地方の府県は，地方の中核となる府 県から災害廃棄物を運搬し，処理することとなる。

5）バックヤード方式による全国連携は, サテライト 方式と同様に全国を 8 地方に区分し, 被災地である首都

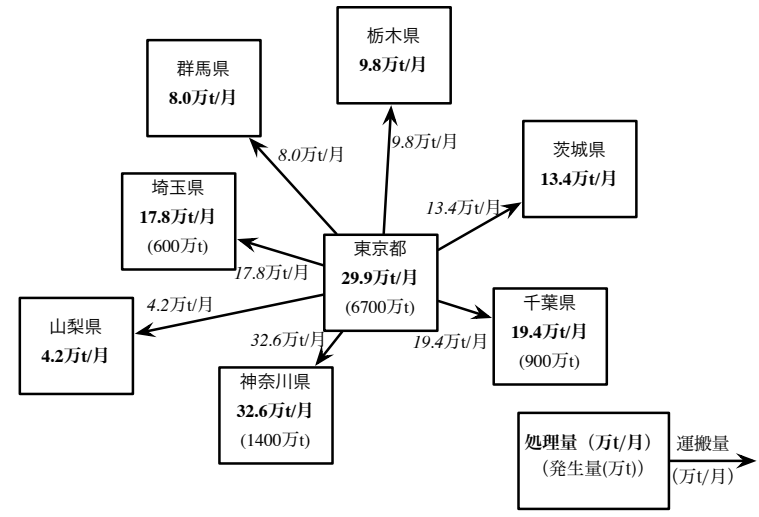

図 -3 首都圈での連携による災害廃棄物処理方策

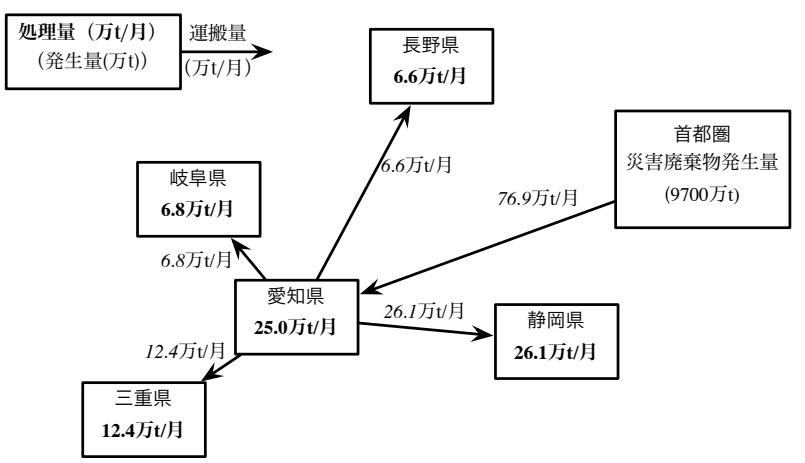

図 -4 サテライト方式による全国連携での中部地方に おける災害廃杗物処理方策

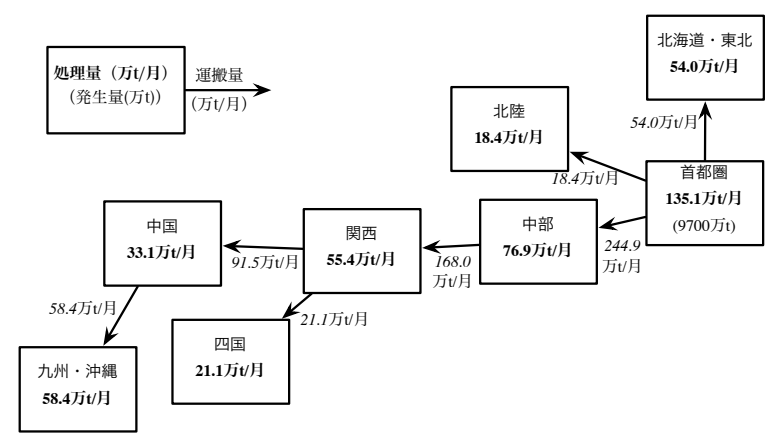

図 -5 バックヤード方式による全国連携での災害廃棄 物処理方策

圈から北海道・東北地方, 北陸地方, 中部地方の 3 地方 に災害廃棄物を運搬し, さらに, 中部地方から近畿地方, 近畿地方から中国, 四国地方, 中国地方から九州・沖縄 地方に運搬する，という多段階による災害廃棄物運搬方 式である。図 -5に概念図を示す。つまり, 各地方は近 接している地方から災害廃棄物を運搬し，道府県はそれ ぞれの地方における中核となる府県から災害廃棄物を運 搬し，処理することとなる.

\section{(3) シミュレーション結果と考察}

\section{a）被災都県個別に対応}

表 -4 にシミュレーション結果を示す。これより，最 も処理期間が少ない埼玉県においても約 3 年の期間が 必要である。一方, 東京都は焱害廃棄物量相対值 $W_{R}$ が 
表 -4 被災都県個別による対応での災害廃棄物処理 期間推定結果

\begin{tabular}{|c|c|c|}
\hline & 処理期間 (ケ月) & 残余年数減少 (年) \\
\hline 埼玉県 & 33.7 & 2.32 \\
千葉県 & 46.4 & 3.88 \\
東京都 & 224.1 & 12.95 \\
神奈川県 & 42.9 & 3.93 \\
\hline
\end{tabular}

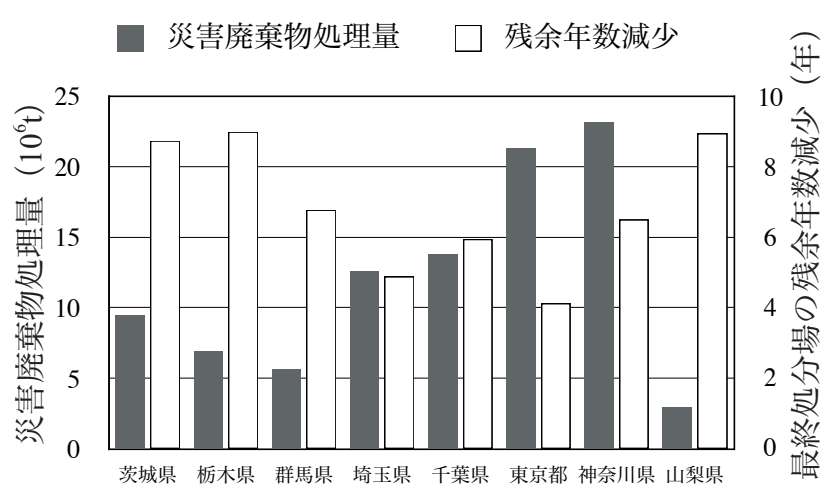

図 -6 首都圏での連携による都県別災害廃棄物処理量

155.4 ケ月であり，処理に必要な期間は 18.6 年となり， 災害廃棄物処理の遅延により復旧・復興がいつまでも進 まないこととなる。 また，阪神・淡路大震災と同程度の 処理能力向上を行つた場合においても 101.2 ケ月, 約 9 年もの期間が必要となると推定された.

また，一般廃棄物最終処分場の残余年数は，東京都で 約 13 年分, 神奈川県, 千葉県で約 4 年分, 埼玉県で約 2 年分消費するといえた。

\section{b) 首都圏での連携}

首都圏での連携による災害廃棄物処理に必要な期間は 71.1 ケ月，5.9年と算出された。 図 -6 に首都圏での連 携による都県別災害廃棄物処理量を示す。これより，災 害廃棄物処理量は，神奈川県，東京都がそれぞれ 2318 万t, 2124万tと 2000 万 $\mathrm{t}$ 以上処理することとなる. また, 一般廃棄物最終処分場の残余年数減少は，東京都が 4.1 年と最も小さくなった。一方，応援県である茨城県，栃 木県, 山梨県では約 9 年もの残余年数が災害廃棄物によ り減少することになるといえた。

\section{c）個別方式による全国連携}

個別方式による全国連携で首都直下地震に係る災害廃 椠物を処理した場合，その処理に必要な期間は 38.4 ケ 月，3.2 年と推定された。

災害廃棄物処理量は, 東京都が 1148 万 t, 神奈川県 が 1252 万 $\mathrm{t}$ となった. また, 応援道府県で処理量が最 も大きいのは, 静岡県で 801 万 $\mathrm{t}$, 次いで茨城県 513 万 $\mathrm{t}$, 大阪府 485 万 $\mathrm{t}$ であった。 応援道府県で 200 万 $\mathrm{t}$ 以上の 災害廃亲物を処理するのは 11 府県となっている. 図 -7 に都道府県別の一般廃棄物最終処分場における残余年数 減少を示す. 全国の都道府県の残余年数減少の平均は 1.6

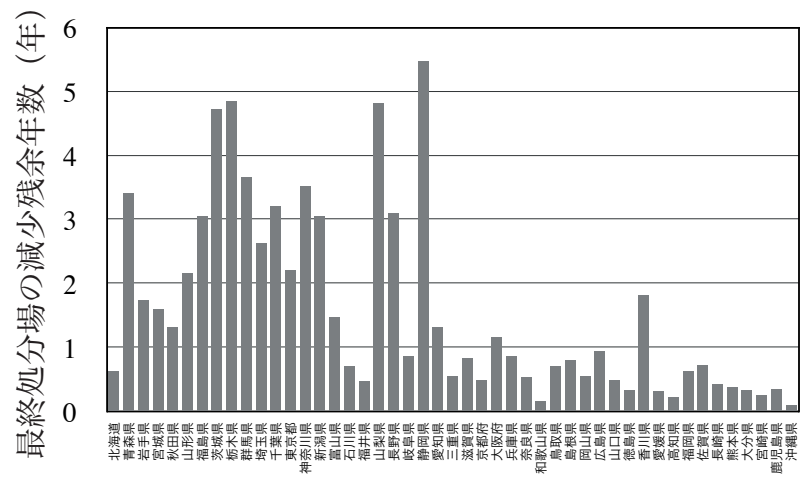

図 -7 個別方式による全国連携での都道府県別の一般 廃棄物最終処分場残余年数減少

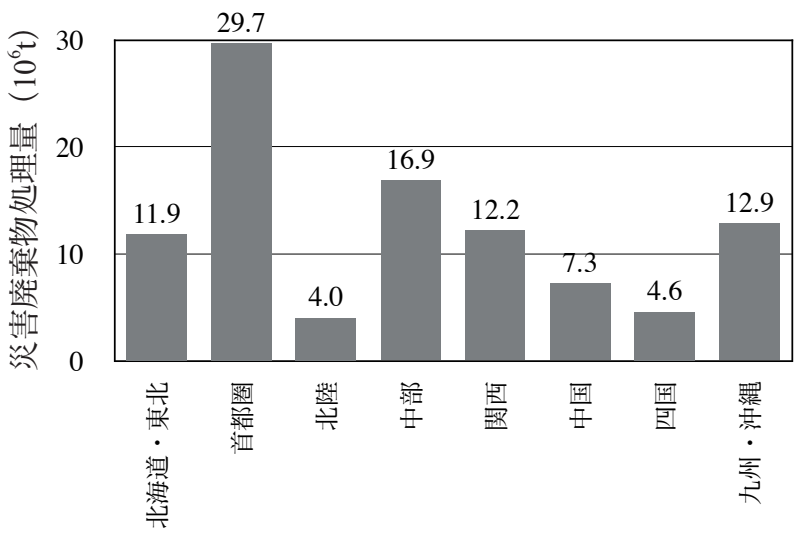

図 -8 バックヤード方式での全国連携による地方別災 害廃棄物処理量

年であり, 最も減少している静岡県で 5.5 ケ月となって いる.

d）サテライト方式による全国連携

サテライト方式による全国連携での災害廃亲物処理期 間は23.4 ケ月と算出された。このとき, 東京都は 700 万 $\mathrm{t}$, 神奈川県は 763 万 $t$, 災害廃棄物を処理することとなる。 200 万 $\mathrm{t}$ 以上の災害廃棄物を処理するのは, 東京都, 神 奈川県, 埼玉県, 千葉県の被災都県以外では, 茨城県, 杤木県, 静岡県, 愛知県, 大阪府の 1 府 4 県であった.

また，一般廃亲物最終処分場の残余年数減少の全国平 均は 2.1 年で, 最も残余年数が減少したのは山口県の 4.3 年であった。

e）バックヤード方式による全国連携

バックヤード方式による全国連携においては，処理に 必要な期間は 21.6 ケ月, 1.8 年と推定された。このとき, 東京都は 645 万 t, 神奈川県 703 万 $\mathrm{t}$ の災害廃棄物を処 理することとなる. 図 -8 に地方別の災害廃棄物処理量 を示す。

\section{（4）まとめと今後の課題}

以上より，それぞれの連携方策において，首都直下地 震に係る災害廃棄物処理期間が推定された。その結果, 


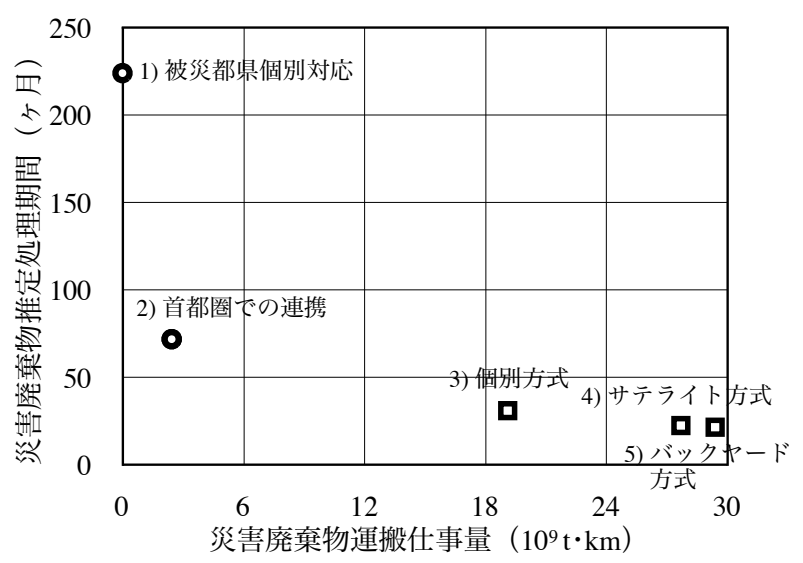

図 -9 首都直下地震に係る災害廃棄物の推定処理期間 と都道府県間運搬仕事量

バックヤード方式による全国連携，あるいは，サテライ 卜方式による全国連携を活用することで，首都直下地震 における災害廃椠物を 2 年以内に処理することができる と推定された。これらの連携方策は，災害廃棄物を平常 時の貨物物流量という制約条件下で，災害廃棄物を，輸 送条件が許す限り被災地域外に搬出するものである。

都道府県間の災害廃棄物運搬に係る仕事量を算出し, 首都直下地震に打ける災害廃棄物の推定処理期間との関 係を図 - 9 に示す。これより，処理期間を短縮すればす るほど, 都道府県間運搬仕事量は増加することとなる。 つまり，首都直下地震に係る災害廃棄物をできるかぎり 迅速に処理するためには，都道府県間を越えた広域的連 携が必要条件であるといえる。

都道府県間相互間地域防災計画あるいは応援協定とい う観点からは，1) 被災都県個別対応は事前に検討して おく必要はなく，2) 首都圈連携についても 1 都 7 県で 検討しておくだけでよいといえる。一方，全国連携であ る 3）個別方式は，東京都が 46 道府県との応援協定を 締結しておく必要がある，4)サテライト方式では，多 くの都道府県は，それぞれの地域内での近隣都道府県と の応援協定を検討していくことが必要であり, 首都圈が 他の 7 地方との連携が求められる。 5）バックヤード方 式についても, サテライト方式と同様，多くの都道府県 は，それぞれの地域内での近隣都道府県との応援協定を 締結しておくことが必要であるが, 首都圈と他の 7 地方 との連携は必ずしも必要であるとはいえない。近隣都道 府県との連携，隣接地方間の連携を，ネットワークとし て活用することで全国連携を行うといえる。つまり，九 州・沖縄地方は首都圈に対して応援業務を行うのではな く，中国地方に対して応援業務を行い，中国地方は関西 地方に対して応援業務を行い，関西地方は中部地方に対 して応援業務に実施すればよいということである.

以上のことから，広域災害に対応できる広域連携方策 を示しえた。本研究は，あくまでも，災害廃裹物量に着
目し，広域災害時における都道府県間の広域連携方策に ついて検討したものである。したがって，今後は，広域 災害時の災害廃棄物処理における問題の実際上の解決に 向けて，市町村における業務の観点から，災害廃棄物の 処理フローや市町村業務である収集過程，処理過程，災 害廃棄物の分別・リサイクル，仮置き場の確保について も検討していくことが重要である，さらに，処理に係る 費用，運般に係る費用などコスト面からの検討も必要で ある。また，広域連携における課題を明らかにし，広域 連携を可能とする情報システム，情報共有手法，さらに は標潐的な業務フローについて検討していくことが重要 である。

\section{5. 結言}

本研究では，行政の災害対応力を考慮したうえで，広 域都市災害時における廃棄物処理の広域応援方策につい て検討した。 以下に得られた知見を示す。

1. 平常時の一般廃棄物排出量からみた災害廃棄物発生 量である災害廃棄物量相対値 $W_{R}$ を用いて, 東海地震, 東南海・南海地震，首都直下地震に係る災害廃棄物に 対する我が国の災害対応力を明らかにした。また，行 政の災害対応力を考慮した災害廃棄物処理期間推定モ デルを構築した。その結果，東海・東南海・南海地震 や首都直下地震に係る災害廃棄物は国難であるとの認 識にたち，この国難をいかに克服していくのかについ て検討しておくことが重要であることを示した。

2. 災害廃棄物の広域連携シミュレーションモデルを構 築し，首都直下地震における災害廃棄物処理に関する 数值シミュレーションを行った。 その結果, サテラ イト方式あるいはバックヤード方式での全国連携に よる災害廃棄物処理に必要な処理期間は，それぞれ 23.4 ケ月，21.6 ケ月と推定された。

3. 広域災害時における災害廃棄物対策では, 都道府県 間を越えた広域的な連携が重要となることを示しえ た.

\section{参考文献}

1) 小林康彦: 災害と廃棄物問題一日本の制度と阪神・淡路大 震災によって明らかになった課題-, 震災廃裹物対策国際 シンポジウム報告書, pp.11-18, 1995.

2) 高月紘, 酒井伸一, 水谷聡, 浦野真弥, 小林純一郎, 伊 藤宏 : 震災により生じる廃棄物の性状と発生量に関する 検討，災害廃棄物フォーラム，pp.19-29，1996.

3) 廃棄物学会研究委員会: 災害等の特殊環境における廃棄 物処理の在り方 災害廃棄物処理現地調査報告書 一阪 神・淡路大震災の復興初期における処理状況,- 1995. 
4) 高月紘, 酒井伸一, 水谷聡, 浦野真弥, 小林純一郎, 伊藤宏： 阪神・淡路大震災における解体廃棄物に関する調査，環 境衛生工学研究, Vol.10, No.3, pp.188-193, 1996.

5) 中道民広, 井上求 : 災害時の廃棄物処理技術, 廃棄物学 会誌, Vol.6, No.5, pp.394-401, 1995.

6) 高月紘, 酒井伸一, 水谷聡 : 災害と廃棄物性状一災害廃棄 物の発生原単位と一般廃衰物組成の変化一, 廃衰物学会誌, Vol.6, No.5, pp.351-359, 1995.

7) 島岡隆行：自然災害における災害廃棄物の発生特性と処 理方策に関する調査研究，廃棄物学会誌，Vol.6, No.5, pp.360-372, 1995.

8) 平山修久, 河田惠昭：水害時における行政の初動対応か らみた災害廃棄物発生量の推定手法に関する研究，環境 システム研究論文集，Vol.33，pp.29-36， 2005.

9) 藤原輝夫 : 神戸市の災害廃棄物対策, 廃棄物学会誌, Vol.6, No.5, pp.380-393, 1995.

10）春風敏之：兵庫県における災害廃棄物処理, 環境衛生工 学研究, Vol.9, No.3, pp.116-120, 1995.

11）粕谷明博, 岩佐恵治：廃棄物処理とそのシステムに関 連して, 環境衛生工学研究, Vol.9, No.3, pp.144-149, 1995.

12）春風敏之, 城戸正輝, 築谷尚嗣：阪神・淡路大震災に おける災害廃棄物処理について, 環境衛生工学研究, Vol.11, No.3, pp.67-72, 1997.

13）厚生省生活衛生局水道環境部：震災廃棄物対策指針, 1998.

14）環境省大臣官房廃棄物・リサイクル対策部：水害廃棄物 対策指針，2005.

15) 平山修久, 河田惠昭：水害時の行政対応における災害廃 棄物発生量に関する研究，地域安全学会論文集，No.7, pp.325-330, 2005.

16） 七都県市廃棄物問題検討委員会 : 適正処理部会調査・検 討報告書，2001.

17) 慶応義塾大学経済学部細田衛士研究会 : 震災廃车物処理 システム確立を目指して，2003.

18）逐条解説災害対策基本法，防災行政研究会，pp.197-233， 2002.
19) 兵庫県，財団法人 21 世紀ひょうご創造協会：がれき等 の災害廃棄物の処理，阪神・淡路大震災復興誌，Vol.1， pp.215-225, 1997.

20) 兵庫県：阪神・淡路大震災兵庫県の 1 年の記録, pp.244-251, 1996.

21）高月紘，酒井伸一，水谷聡：災害と廃楂物性状-災害廃棄 物の発生原単位と一般廃棄物組成の変化一, 廃椠物学会誌, Vol.6, No.5, pp.351-359, 1995.

22) 渡辺信久：阪神・淡路大震災における災害廃棄物の発 生特性，災害廃棄物フォーラム講演論文集，pp.93-110， 1996.

23）中央防災会議「東海地震対策専門調査会」：東海地震に係 る被害想定結果，2003.

24）中央防災会議「東南海，南海地震等に関する専門調査会」: 東南海，南海地震の被害想定について，2003.

25）中央防災会議「首都直下地震対策専門調査会」：首都直下 地震の被害想定について，2005.

26）環境省大臣官房廃棄物・リサイクル対策部：日本の廃棄 物処理平成 15 年度版, 2006 .

27）消防庁：阪神・淡路大震災について (確定報), 2006.

28） 入江登志男, 森一男 : 大阪湾広域臨海環境整備センター 事業の現況と兵庫県南部地震災害廃棄物の搬入状況等に ついて, 環境衛生工学研究, Vol.9, No.3, pp.150-151, 1995.

29）環境省大臣官房廃棄物・リサイクル対策部 : 平成 17 年度 事業産業廃棄物排出・処理状況調査報告書平成 15 年度実 績, 2006.

30) 築谷尚嗣: 平成 16 年台風 23 号により発生した災害廃棄 物の処理について，都市清掃，Vol.59，No.271，pp.9-13， 2006.

31) 環境省 : 平成 15 年度一般廃棄物処理事業実態調査結果, 廃棄物処理技術情報，2006.

32）国土交通省：第 7 回全国貨物純流動（物流センサス）調 査報告書，2002。

(2006. 7. 3 受付)

\title{
WIDE-AREA COOPERATIVE MEASURES IN THE EMERGENCY DEBRIS OPERATION ON THE HUGE EARTHQUAKE DISASTERS
}

\author{
Nagahisa HIRAYAMA and Yoshiaki KAWATA
}

With the relative value of the quantity of disaster waste calculated by the estimated debris and the amount of garbage total exhaust in annual, the disaster response capacity of public authorities in the huge earthquake disasters was estimated. A numerical simulation model for wide-area cooperative measures in the emergency debris operation was developed. The required period for emergency debris operation with wide-area cooperation by the backyard method on earthquake disaster in the Tokyo Metropolitan area was estimated at 21.6 months. In addition, it was indicated that the required period for debris operation in the huge earthquake disasters was influenced by the wide-area cooperative measures. 